\title{
Allelopathic Potential of Compounds in Selected Crops
}

\author{
M. G. Kaiira ${ }^{1}$, G. N. Chemining'wa ${ }^{2}$, F. Ayuke ${ }^{3}$, Y. Baguma ${ }^{4}$ \& E. Atwijukire ${ }^{4}$ \\ ${ }^{1}$ Buginyanya Zonal Agricultural Research and Development Institute, Mbale, Uganda \\ ${ }^{2}$ Department of Plant Science and Crop Protection, University of Nairobi, Nairobi, Kenya \\ ${ }^{3}$ Department of Land Resource Management and Agricultural Technology, University of Nairobi, Nairobi, \\ Kenya \\ ${ }^{4}$ National Crops Resources Research Institute (NaCRRI), Namulonge, Uganda \\ Correspondence: M. G. Kaiira, Buginyanya Zonal Agricultural Research and Development Institute, Mbale, \\ Uganda. E-mail: moseskaiira@gmail.com
}

Received: October 28, 2019

Accepted: December 5, 2019 Online Published: August 15, 2021

doi:10.5539/jas.v13n9p192

URL: https://doi.org/10.5539/jas.v13n9p192

\begin{abstract}
Allelochemicals cause yield differences under various ecosystems worldwide. Studies were conducted at the National Crops Resources Research Institute, Namulonge, Uganda during 2016 to investigate allelopathic properties of bioactive compounds in upland rice (NERICA 1), Desmodium uncinatum, Zea mays (LONGE 6H) and Mucuna pruriens root leachates. Studies involved pot screening, equal compartment agar experiments, germination tests and growth of potted plants. Results under the pot study indicated that maize, rice and mucuna leachates significantly $(\mathrm{P} \leq 0.05)$, reduced root lengths $(49 \%-63 \%)$, plant heights $(48 \%-66 \%)$ and biomass (63\%-75\%) for Ageratum conyzoides, Bidens pilosa and Gallinsoga. parviflora weeds. G. parviflora root growth was reduced (20\%-41\%) and stem growth declined (19\%-42\%) when maize, rice and mucuna leachates were applied in the equal compartment agar study. Increased leachate concentrations (25\%-75\%) significantly (P $\leq$ $0.05)$, increased the mean germination time (0.4-2.8 days) for mucuna, desmodium, rice and maize as seed germination indices (SGI) were reduced (1.3\%-49\%). Potted mucuna, maize and desmodium reduced $(1.3 \%-49 \%)$ rice root length. Potting mucuna with maize reduced $(32 \%)$ mucuna leaf width while desmodium growth parameters were reduced (49\%-64\%) when potted with maize and mucuna. Potting maize with mucuna or desmodium increased the maize leaf length (18\%) and SGI (25). Application of higher (25\%-75\%) rice/maize leachate concentrations similarly increased the maize leaf length (31\%) and SGI (119). Allelopathic properties affect seed germination, crop growth and development, and characterise ecosystems age structures. Strategic management of crops under allelopathic ecosystems is critical.
\end{abstract}

Keywords: allelochemicals, leachates, maize, mean germination time, rice, seed germination indices

\section{Introduction}

The properties of bioactive compounds in allelopathic plants influence the productivity and lifespan of species under various ecosystems. Several allelopathic interactions of agricultural importance have been reported including crop to weed, weed to crop, crop to crop, plant to insect and plant to pathogen, thereby, affecting the economical outcomes of plant production (Zohaib et al., 2016; Abbas et al., 2017). Allelopathic effects of poor establishment and stunted crop growth due to auto-toxification, resulting from growing the same crop on the same land in succeeding years have been observed in managed agricultural ecosystems (Singh et al., 1999). Inhibitory effects on germination and establishment of crops and weeds caused by crop residues have been reported (Zohaib et al., 2016; Ashraf et al., 2017). Effects on foliar enzyme activity, protein synthesis, photosynthesis, respiration, cell division and enlargement were observed by several researchers (Nishida et al., 2005; Cai \& Mu, 2012; Esmaeili \& Heidarzade, 2015), resulting in significant reductions in crop yields.

The properties of allelochemicals are expressed by the mode of action of a chemical and can be broadly divided into a direct and an indirect action. The direct action involves the biochemical physiological effects of allelochemicals on various important processes of plant growth and development. Effects through the alteration of soil properties, nutritional status, population or activity of micro-organisms and nematodes represent the indirect action (Rizvi et al., 1992). The authors further noted that allelochemicals are more concentrated in the 
leaves, stem or roots than in the fruits or flowers. Allelochemicals are released in four ways namely volatilization, leaching, exudation, and decomposition of plant residues (Rice, 1984).

Allelopathic properties of allelochemicals have been reported on weeds, companion, and subsequent crops. Pickett et al. (2010) observed a putative allelopathic mechanism for Desmodium uncinatum when an aqueous solution from D. uncinatum plants was applied. Kong et al. (2008), observed reduced growth of Echinochloa. Crus-galli in rice paddy fields and attributed it to allelochemicals released by the rice roots. Ayeni and Kayode (2014) reported aqueous stem extracts from Sorghum bicolor and maize inhibited the okra (sci. name) seed germination. Nwaichi and Edward (2010) reported suppression of plant growth indices on crops in companion with mucuna due to allelopathic effects. Soares et al. (2014) reported that L-DOPA from the mucuna roots reduced the growth of neighboring plants. Pieterse (2010) reported that allelochemicals could be used to manipulate biosynthesis of putative compounds for weed management. Allelopathic properties of bioactive compounds in maize, rice, desmodium and mucuna have not been established. Therefore, the objective of the study was to determine the allelopathic properties of the bioactive compounds in these crops.

\section{Materials and Methods}

This study was conducted in the laboratory and screen house at the National Crops Resources Research Institutes (NACRRI) Namulonge, Uganda during 2016.

\subsection{Pot Screening Study}

Desmodium uncinatum, Mucuna pruriens and Zea mays crops were screened for their allelopathic potential against rice accessions in three subsequent stages. In the first preliminary non replicated screening stage, five 4-day old pre-germinated seeds, each of six upland rice accessions (NERICA 1, NERICA 4, NERICA 10, NAMCHE 1, NAMCHE 2 and NAMCHE 3) were potted with five 4-day old pre-germinated seeds, each of desmodium, mucuna and three maize accessions ( LONGE 6H, M17 and M25).

The $10 \times 10 \mathrm{~cm}$ top diameter pots contained $300 \mathrm{~g}$ of sandy-loam soil (USDA classification system). Each of the crops was also planted alone in similar pots as a control (Dayan et al., 2009). An initial watering of $80 \mathrm{ml}$ followed by $120 \mathrm{ml}$ of tap water was applied to each pot every two days. At stage two, NERICA 1 and LONGE $6 \mathrm{H}$ maize were selected for stage three based on three growth parameter, namely leaf number, plant height and length of roots on uprooted samples. The parameters were measured weekly for three consecutive weeks on each rice and maize accession under a randomized complete block design (RCBD) with three replicates. At stage three, NERICA 1, LONGE 6H, maize, mucuna and desmodium were used to demonstrate allelopathy on three receiver common rice weeds, namely Gallinsoga parviflora, Bidens pilosa and Ageratum conyzoides. Similar pots, arranged in RCBD with three replicates, were planted separately with pre-germinated seeds to raise rice (three plants), maize (one plant), mucuna (one plant) and desmodium (five plants) per pot. The pots received $80 \mathrm{ml}$ of tap water initially and were leached with an additional $200 \mathrm{ml}$ of water on day 4, 6, 8 and 10, respectively, and the leachates were collected for subsequent use. Ten milliliter portions of the leachates collected on each of the days were applied to the soil in pots with ten receiver weed seeds under three replicates. Weeds receiving tap water at the same time intervals were used as controls.

\subsection{Equal Compartment Agar Experiment}

In the equal compartment agar experiment (Hilt et al., 2012), a piece of semi permeable vinyl acetate fiber was inserted across the center and down the middle of a glass beaker pre-filled with $0.1 \%$ standard nutrient agar solution. The fiber divided the beaker into two equal compartments, with the lower edge of the membrane kept

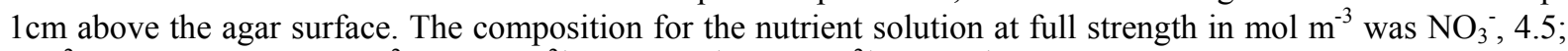
$\mathrm{SO}_{4}{ }^{2-}, 2.0 ;\left[\mathrm{H}_{2} \mathrm{PO}_{4}{ }^{-}+\mathrm{HPO}_{4}{ }^{2-}\right]$ 0.08; $\mathrm{Ca}^{2+}, 2.0 ; \mathrm{NH}_{4}{ }^{+}, 0.5 ; \mathrm{Mg}^{2+}, 0.4 ; \mathrm{K}^{+}, 3.3$. Five pre-germinated donor seeds of each of the screened allelopathic plants; rice, desmodium and maize, including three pre-germinated mucuna seeds were uniformly selected and separately sown on the agar surface in one-half of a glass beaker. The beakers were kept under a controlled growth cabinet in the laboratory. After 7 days of seedlings growth, 10 pre-germinated seeds of each receiver weed species, namely Gallinsoga, Bidens, and Ageratum were sown in the second half of the agar surface. This allowed the molecules to move between the donor and receiver plants, but did not allow root to root contact. The beaker was placed back in the growth cabinet for seven more days when the weeds were harvested.

\subsection{Germination Test Experiment}

The experiment was conducted at NaCRRI laboratories to determine the allelopathic effects of bioactive compounds on germination of test plants. The stored leachates (100\%) from maize, mucuna, rice, and desmodium pot screening experiment conducted earlier were constituted to $25 \%, 50 \%$, and $75 \%$ concentrations 
and used in this study with a control treatment with tap water. Ten seeds of test crops, namely rice, desmodium, mucuna, and maize were washed with tap water and put in petri-dishes on Whatman No.1 filter paper in four sets replicated three times under laboratory conditions. About $10 \mathrm{ml}$ of the different leachate concentrations and tap water were added daily to the sets of petri-dishes of test plants and the control, respectively for nine consecutive days as described by Hagan et al. (2013).

\subsection{Donor to Receiver Plants}

In the donor to receiver experiment, pre-germinated seedlings of each of the receiver plants namely maize (1 seedling), mucuna ( 1 seedling) and desmodium (4 seedlings) were planted separately with rice (4 seedlings) in the same pot as a donor to demonstrate the allelopathic potential of rice on receiver plants. The pre-germinated seedlings were also planted as sole maize ( 1 seedling), mucuna ( 1 seedling), desmodium ( 4 seedlings) and rice (4 seedlings) as described by Dayan et al. (2009). Each pot received an initial watering of $80 \mathrm{ml}$ followed by 200 $\mathrm{ml}$ of tap water every 2 days for 3 consecutive weeks and no fertilizers were applied.

\subsection{Data Recording}

In the pot screening study, leaves were counted, plant heights measured, and the longest roots were measured for each rice and maize cultivar weekly, for three consecutive weeks to select crops for stage 2 of the research study. In the potting and equal compartment agar studies, root and shoot lengths of the weeds were measured, and the weed samples were oven dried at $80{ }^{\circ} \mathrm{C}$ for 12 hours until constant weight to determine the dry biomass. In the germination study, radicle and plumule lengths, seed germination percentage $(\mathrm{G} \%)$, and mean germination time (MGT), taken as time from imbibition to radicle emergence, were determined for ten successive days. The combined shoot and root dry weights were determined on the $11^{\text {th }}$ day. Seed germination percentage was calculated using the formula: $\mathrm{G} \%=(a / b) \times 100$; where, $a$ was the number of germinated seeds and $b$ the total number of seeds in treatment. Mean germination time (MGT) was calculated as: MGT $=\Sigma(n \times d) / \mathrm{N}$, where, $n$ was the number of seeds which germinated after each period in days $(d)$ and $\mathrm{N}$ was the total number of seeds that germinated at the end of the experiment (AOSA, 1983). The seed germination index (SGI) was also calculated as described by AOSA (1983) using the following formula: SGI = Summation of number of germinated seeds/days of first count up to observations under the last count. The crops were uprooted at 21 days after planting, shoot and root length were measured and the plant materials oven dried at $80{ }^{\circ} \mathrm{C}$ for 12 hours until constant weight to determine the dry matter biomass. In the donor to receiver plants in the same pot data was collected on root length, plant height, dry biomass, leaf number, leaf length and leaf width of rice, maize, mucuna and desmodium.

\subsection{Data Analysis}

Collected data were subjected to analysis of variance (ANOVA) using Genstat statistical package $\left(13^{\text {th }}\right.$ edition, 2013). The significant differences between treatment means were separated using Fischer's least significant difference (LSD) test at $\mathrm{P} \leq 0.05$.

\section{Results}

\subsection{Effects of Crop Root Leachates on Growth and Development of Weeds}

In the pot screening study, mucuna, desmodium, maize and rice leachates reduced the root length (49\%-63\%), height (48\%-66\%) and plant biomass (63\%-75\%) of Ageratum conyzoides weeds (Table 1). Desmodium leachate caused the greatest percentage reduction in Bidens pilosa weed root length (69\%), stems (30\%), and total biomass (44\%). Mucuna, rice and maize leachates, similarly, significantly $(\mathrm{p} \leq 0.05)$, reduced $B$. pilosa root length and height. Mucuna, desmodium, rice and maize leachates reduced G. parviflora weed root length (21\%-39\%) and plant height (20\%-42\%). Maize leachates reduced Gallinsoga root length (39\%) but the rice leachate had no effect on G. parviflora root length. Tap water produced the tallest G. parviflora weeds. In the equal compartment agar study maize root exudates reduced the G. parviflora weed root length $(41 \%)$ and stem height $(20 \%)$, while rice exudates reduced G. parviflora weed root and stem lengths (28\%). Mucuna root exudates reduced G. parviflora root length $(32 \%)$ and stem height (31\%) relative to the control. Gallinsoga weeds did not influence the growth parameters of maize, rice, or mucuna. In the pot experiment and equal compartment agar study, results indicated that root leachates controlled weed plant parts with different efficacy, and the roots were more susceptible than shoots. 
Table 1. Root length, plant height and dry biomass of A. conyzoides, B. pilosa and G. parviflora weeds as influenced by leachates from M. pruriens, D. uncinatum, Upland NERICA 1 and Z. mays (LONGE 6H)

\begin{tabular}{|c|c|c|c|c|c|c|c|c|c|}
\hline \multirow{3}{*}{ Leachate Type } & \multicolumn{9}{|c|}{ Receiver Weeds } \\
\hline & \multicolumn{3}{|c|}{ Ageratum conyzoides } & \multicolumn{3}{|c|}{ Bidens pilosa } & \multicolumn{3}{|c|}{ Gallinsoga parviflora } \\
\hline & $\begin{array}{l}\text { Root Length } \\
(\mathrm{cm})\end{array}$ & $\begin{array}{l}\text { Plant Height } \\
(\mathrm{cm})\end{array}$ & $\begin{array}{l}\text { Biomass } \\
(\mathrm{g})\end{array}$ & $\begin{array}{l}\text { Root Length } \\
(\mathrm{cm})\end{array}$ & $\begin{array}{l}\text { Plant Height } \\
(\mathrm{cm})\end{array}$ & $\begin{array}{l}\text { Biomass } \\
(\mathrm{g})\end{array}$ & $\begin{array}{l}\text { Root Length } \\
(\mathrm{cm})\end{array}$ & $\begin{array}{l}\text { Plant Height } \\
(\mathrm{cm})\end{array}$ & $\begin{array}{l}\text { Biomass } \\
(\mathrm{g})\end{array}$ \\
\hline Control (Tap Water) & $3.15 \mathrm{a}$ & $5.54 \mathrm{a}$ & $0.08 \mathrm{a}$ & $4.36 \mathrm{a}$ & $9.57 \mathrm{a}$ & $0.27 \mathrm{a}$ & $3.23 \mathrm{a}$ & $5.05 \mathrm{a}$ & $0.12 \mathrm{a}$ \\
\hline Rice & $1.38 \mathrm{~b}$ & $1.89 \mathrm{~d}$ & $0.02 \mathrm{~b}$ & $2.33 \mathrm{c}$ & $7.10 \mathrm{c}$ & $0.27 \mathrm{a}$ & $3.28 \mathrm{a}$ & $3.97 \mathrm{~b}$ & $0.05 \mathrm{a}$ \\
\hline Maize & $1.22 \mathrm{~b}$ & $2.50 \mathrm{c}$ & $0.02 \mathrm{~b}$ & $2.45 \mathrm{c}$ & $8.28 \mathrm{~b}$ & $0.27 \mathrm{a}$ & $1.98 \mathrm{~d}$ & $4.03 b$ & $0.31 \mathrm{a}$ \\
\hline Desmodium & $1.51 \mathrm{~b}$ & $3.03 \mathrm{~b}$ & $0.03 \mathrm{~b}$ & $1.35 \mathrm{~d}$ & $6.73 \mathrm{~d}$ & $0.15 b$ & $2.05 \mathrm{c}$ & $3.85 \mathrm{c}$ & $0.09 \mathrm{a}$ \\
\hline Mucuna & $1.61 \mathrm{~b}$ & $2.88 \mathrm{~b}$ & $0.02 b$ & $3.69 b$ & $7.16 \mathrm{c}$ & $0.26 \mathrm{a}$ & $2.60 \mathrm{~b}$ & $2.93 \mathrm{~d}$ & $0.04 \mathrm{a}$ \\
\hline P-value & $<0.005$ & $<0.001$ & $<0.001$ & $<0.001$ & $<0.001$ & $<0.001$ & $<0.001$ & $<0.001$ & 0.46 \\
\hline $\operatorname{LSD}(\mathrm{P} \leq 0.05)$ & 0.90 & 0.22 & 0.02 & 0.10 & 0.12 & 0.03 & 0.06 & 0.11 & NS \\
\hline
\end{tabular}

Note. $\mathrm{NS}=$ Not significant.

\subsection{Effects of Crop Root Leachate Concentration on Seed Mean Germination Time}

M. pruriens, D. uncinatum, Upland NERICA 1 and Z. mays (LONGE 6H) seed germination was not influenced by changes in the concentrations of different leachates. However, the mean germination time (MGT) at $75 \%$ concentration under rice + desmodium mixed leachate significantly $(\mathrm{P} \leq 0.05)$ increased for seeds of mucuna (0.4 days), desmodium (0.9 days), rice (2.1 days) and maize ( 0.6 days) relative to the control (Table 2$)$. The MGT similarly increased at $75 \%$ concentration under rice + mucuna mixed leachate for seeds of mucuna (1.0 days), desmodium (0.4 days), rice (2.3 days) and maize (2.1 days) relative to the control. The MGT for desmodium (0.8 days), rice (0.6days) and maize (2.8 days) seeds at $75 \%$ rice + maize mixed leachate concentration was also greater than under the control. Rice + mucuna mixed leachates recorded greater MGT for mucuna, desmodium and maize seeds than rice + desmodium mixed leachates. The MGT for rice seeds under rice + maize mixed leachates was greater than under rice + mucuna and rice + desmodium mixed leachates. MGT for maize seeds under rice + maize mixed leachates was less than under rice + desmodium and rice + mucuna mixed leachates.

Table 2. Mean germination time for mucuna, desmodium, rice and maize under Rice + Desmodium, Rice + Mucuna and Rice + Maize mixed leachates at different concentrations

\begin{tabular}{|c|c|c|c|c|c|c|c|c|c|c|c|c|}
\hline \multirow{3}{*}{ Concentration (\%) } & \multicolumn{12}{|c|}{ Mixed Leachate } \\
\hline & \multicolumn{4}{|c|}{ Rice + Desmodium } & \multicolumn{4}{|c|}{ Rice + Mucuna } & \multicolumn{4}{|c|}{ Rice + Maize } \\
\hline & Mucuna & Des & Rice & Maize & Mucuna & Des & Rice & Maize & Mucuna & Des & Rice & Maize \\
\hline & & & & & Mean & Germinat & on Time ( & days) ----- & -------- & ---- & - & ------- \\
\hline $75 \%$ & $4.90 \mathrm{a}$ & $7.60 \mathrm{a}$ & $6.80 \mathrm{a}$ & $7.70 \mathrm{a}$ & $5.90 \mathrm{a}$ & $8.00 \mathrm{a}$ & $6.90 \mathrm{a}$ & $7.90 \mathrm{a}$ & $4.90 \mathrm{a}$ & $7.80 \mathrm{a}$ & $7.70 \mathrm{a}$ & $6.90 \mathrm{a}$ \\
\hline $50 \%$ & $4.80 \mathrm{~b}$ & $7.10 \mathrm{~b}$ & $4.90 \mathrm{~b}$ & $7.60 \mathrm{~b}$ & $5.00 \mathrm{~b}$ & $7.90 \mathrm{a}$ & $4.90 \mathrm{~b}$ & $7.50 \mathrm{~b}$ & $4.90 \mathrm{a}$ & $7.50 \mathrm{~b}$ & $7.60 \mathrm{~b}$ & $4.90 \mathrm{~b}$ \\
\hline $25 \%$ & $4.60 \mathrm{c}$ & $7.30 \mathrm{~b}$ & $4.90 \mathrm{c}$ & $7.20 \mathrm{c}$ & $4.90 \mathrm{c}$ & $7.40 \mathrm{~b}$ & $4.90 \mathrm{~b}$ & $7.10 \mathrm{c}$ & $4.80 \mathrm{~b}$ & $7.30 \mathrm{~b}$ & $7.20 \mathrm{c}$ & $4.70 \mathrm{c}$ \\
\hline $0 \%$ (Control) & $4.50 \mathrm{~d}$ & $6.70 \mathrm{c}$ & $4.70 \mathrm{c}$ & $7.10 \mathrm{~d}$ & $4.90 \mathrm{c}$ & $7.60 \mathrm{~b}$ & $4.70 \mathrm{~b}$ & $7.10 \mathrm{c}$ & $4.90 \mathrm{~b}$ & $7.00 \mathrm{c}$ & $7.10 \mathrm{~d}$ & $4.10 \mathrm{~d}$ \\
\hline P-Value & $<0.001$ & 0.012 & $<0.001$ & $<0.001$ & $<0.001$ & $<0.001$ & $<0.001$ & $<0.001$ & $<0.001$ & $<0.001$ & $<0.001$ & $<0.001$ \\
\hline $\operatorname{LSD}(\mathrm{P} \leq 0.05)$ & 0.04 & 0.49 & 0.08 & 0.05 & 0.05 & 0.37 & 0.49 & 0.04 & 0.03 & 0.27 & 0.05 & 0.15 \\
\hline
\end{tabular}

Note. Des $=$ Desmodium.

\subsection{Effects of Concentration of Mixed Leachates on Seed Germination Indices}

Increased concentrations $(25 \%-75 \%)$ of rice + desmodium leachate significantly $(\mathrm{P} \leq 0.05)$, reduced the seed germination indices (SGI) for mucuna (30\%), desmodium (6\%) and rice $(25 \%)$. An increase in the rice + mucuna leachate concentration (25\%-75\%) reduced the SGI for desmodium $(24 \%)$, rice $(28 \%)$ and maize $(43 \%)$. The SGI was reduced with an increase $(25 \%-75 \%)$ in rice + maize leachate concentration for mucuna $(7 \%)$, desmodium $(26 \%)$, and rice $(4 \%)$ an in Table 3. The SGI for maize increased at higher $(25 \%$-75\%) rice + desmodium (4\%) and rice + maize (18\%) leachate concentration relative to the control. Mucuna seeds SGI was not influenced by mixed rice + mucuna leachate concentrations, but reduced relative to the control. Rice + maize 
mixed leachate lowered the SGI for desmodium seeds relative to rice + desmodium and rice + mucuna mixed leachates between $25 \%$ and $75 \%$ leachate concentrations.

Table 3. Seed germination indices for mucuna, desmodium, rice and maize under mixed leachates

\begin{tabular}{|c|c|c|c|c|c|c|c|c|c|c|c|c|}
\hline \multirow{3}{*}{ Concentration $(\%)$} & \multicolumn{12}{|c|}{ Mixed Leachates } \\
\hline & \multicolumn{4}{|c|}{ Rice + Desmodium } & \multicolumn{4}{|c|}{ Rice + Mucuna } & \multicolumn{4}{|c|}{ Rice + Maize } \\
\hline & Mucuna & Des & Rice & Maize & Mucuna & Des & Rice & Maize & Mucuna & Des & Rice & Maize \\
\hline & & & & & $\cdots$ & ed Gern & ination In & lices ---- & - & ------- & - & --------- \\
\hline $75 \%$ & $5.00 \mathrm{~d}$ & $6.60 \mathrm{c}$ & $5.70 \mathrm{~d}$ & $4.50 \mathrm{a}$ & $7.60 \mathrm{~b}$ & $5.70 \mathrm{~d}$ & $5.70 \mathrm{~b}$ & $2.50 \mathrm{c}$ & $6.80 \mathrm{~d}$ & $3.20 \mathrm{c}$ & $5.10 \mathrm{c}$ & $7.90 \mathrm{a}$ \\
\hline $50 \%$ & $6.10 \mathrm{c}$ & $7.00 \mathrm{~b}$ & $7.50 \mathrm{c}$ & $4.50 \mathrm{a}$ & $7.60 \mathrm{~b}$ & $7.00 \mathrm{c}$ & $7.90 \mathrm{a}$ & $4.30 \mathrm{~b}$ & $7.10 \mathrm{c}$ & $4.40 \mathrm{~b}$ & $5.20 \mathrm{c}$ & $7.80 \mathrm{~b}$ \\
\hline $25 \%$ & $7.20 \mathrm{~b}$ & $7.00 \mathrm{~b}$ & $7.60 \mathrm{~b}$ & $4.30 \mathrm{~b}$ & $7.60 \mathrm{~b}$ & $7.50 \mathrm{a}$ & $7.90 \mathrm{a}$ & $4.40 \mathrm{a}$ & $7.30 \mathrm{~b}$ & $4.30 \mathrm{~b}$ & $5.30 \mathrm{~b}$ & $6.70 \mathrm{c}$ \\
\hline $0 \%$ (Control) & $7.70 \mathrm{a}$ & $7.60 \mathrm{a}$ & $7.70 \mathrm{a}$ & $3.60 \mathrm{c}$ & $7.70 \mathrm{a}$ & $7.30 \mathrm{~b}$ & $7.90 \mathrm{a}$ & $4.40 \mathrm{a}$ & $7.70 \mathrm{a}$ & $6.80 \mathrm{a}$ & $7.70 \mathrm{a}$ & $3.60 \mathrm{~d}$ \\
\hline P-value & $<0.001$ & 0.001 & $<0.001$ & $<0.01$ & $<0.001$ & 0.001 & $<0.001$ & $<0.001$ & $<0.001$ & $<0.001$ & $<0.001$ & $<0.001$ \\
\hline $\operatorname{LSD}(\mathrm{P} \leq 0.05)$ & 0.64 & 0.05 & 0.05 & 0.03 & 0.05 & 0.07 & 0.05 & 0.04 & 0.06 & 0.1 & 0.11 & 0.06 \\
\hline $\mathrm{CV}(\%)$ & 0.5 & 0.5 & 0.3 & 0.5 & 0.4 & 0.4 & 0.5 & 0.5 & 0.4 & 0.6 & 0.9 & 0.5 \\
\hline
\end{tabular}

Note. Values with different letters in a column are significantly different at $\mathrm{P} \leq 0.05$. Des $=$ Desmodium.

Rice + maize mixed leachate reduced the SGI for desmodium more than rice + desmodium and rice + mucuna mixed leachates between $25 \%$ and $75 \%$ concentrations.

\subsection{Effects of Leachate Concentrations on Maize Growth and Biomass}

An increase in rice + mucuna and rice + desmodium leachate concentration $(25 \%-75 \%)$ had no effect on maize root length and dry biomass. However, increasing the rice + maize leachate concentration from $25 \%$ to $75 \%$ significantly $(\mathrm{P} \leq 0.05)$ increased the maize root length and biomass by $37 \%$ and $61 \%$, respectively. Maize root lengths under rice + maize leachate $(8.60 \mathrm{~cm})$ and tap water were similar. The maize biomasses under tap water, $25 \%$ and at $50 \%$ rice + maize leachate concentration were also similar. A significantly greater maize biomass of $3.60 \mathrm{~g}$ was recorded at a $75 \%$ increased concentration of rice + maize leachate. Maize plant height was not influenced by types of leachates and changes in their concentrations. Increasing rice + maize and rice + desmodium leachate concentrations and potting maize with mucuna or desmodium raised the maize seed germination indices, growth and development.

\subsection{Effects of Potting Rice, Maize, Mucuna and Desmodium of Crop Growth}

Root length for rice was reduced (30\%-46\%) due to potting with mucuna, maize and desmodium. But, potting maize with mucuna and desmodium increased maize leaf length (15\%-24\%). Mucuna leaf width were reduced $(32 \%)$ when potted with maize while, potting maize with mucuna and desmodium reduced $(49 \%-64 \%)$ the desmodium root length, leaf number, leaf length, leaf width, and plant height.

\section{Discussion}

\subsection{Effects of Crop Root Leachates on Growth and Development of Weeds}

The reduced A. conyzoides, B. pilosa and G. parviflora weed root length, stem height, and biomass may be attributed to allelopathic inhibitory influences of secondary metabolites in root leachates and exudates of mucuna, rice, maize and desmodium crops, possibly stimulated by allelochemicals from the weeds and released via roots to weeds. Kaiira et al. (2019) profiled 2-ethylhexanol phenol, one alkane named 2,3-dimethylundecane, two terpenoids identified as tert-amylbenzene and 1-sec-butyl-4methylbenzene and a furan called 2-pentylfuran in root exudates of both rice (NERICA 1) and Desmodium uncinatum. Rice also pre-dominantly released other terpenoids identified as 1,2-dimethyl-3-ethyl benzene, 1-methyl-2-(2-propenyl)benzene, 1,3-di-tert-butylbenzene and pentamethylbenzine. Desmodium and maize solely released 2-Ethyl-p-xylene terpenoid and p-ethyltoluene was exudated by desmodium alone. The researchers also identified in maize (LONGE 6H) root exudates metabolites that included six terpenoids namely m-ethyl toluene; 1,2,4-trimethylbenzene, O-dichlorobenzene, 1,2,3-trimethyl benzene, 1-methy-2-(2-propenyl) benzene and 2-ethyl-p-xylene. One furan called 2-n-pentylfuran was commonly found in rice and desmodium root exudates. The researchers also noted Mucuna pruriens to release seven organic compounds in the root exudates that included five terpenoids namely naphthalene, 1,2-dimethyl-4-ethylbenzene, 1-ethyl-3-methyl-benzene, 1,3-ditertiarybutylbenzene and 1,3-dichloro-benzene. The latter metabolite was also released by rice crop. Mucuna also released an alkane called n-tetradecane and a phenol identified as dihydrocarveol in the root exudates. The terpenoids that 
dominated the test plants root exudates together with the alkanes, furans, and phenolic compounds could have inhibited protein, lipid and amino acid synthesis, respiration and photosynthesis, reducing weed growth.

Allelochemicals have been reported to influence the physiological and biological processes of plants especially cell division. Crop roots have been reported as more susceptible than other plant parts. Li et al. (2010) observed inhibited root growth, damaged seed cell membrane systems for mitochondria and chloroplasts, increased cell permeability, and consequently reduced crop growth rates by allelochemicals from of seedlings of $M$. pruriens and other crop species. Esmaeili and Heidarzade (2015) indicated that rice root exudates recorded the greatest inhibitory effects on chlorophyll, leaf area, root growth, and nitrogen content. Hooper et al. (2015) reported root exudates of $D$. uncinatum inhibited weed growth.

The differences in weed control observed in results may be attributed to different modes of action, concentration and efficacy of the different secondary metabolites identified in root exudates of desmodium, rice, maize and mucuna crops. The results are supported by Namkeleja et al. (2013) who reported leaf and seed extracts of allelopathic plants reduced seed germination, root and shoot length, fresh weight and dry weight of weed species. The research findings from this study suggest the high possibility of developing bio-herbicides from the bio-active compounds in mucuna, desmodium, maize, and rice. Datta and Saxena (2001) indicated allelopathic crop species as a potential resource with phytotoxic properties against a broad range of weeds.

\subsection{Effects of Concentrations of Mixed Leachates on Seed Germination}

Mean germination time (MGT) for mucuna, desmodium, rice, and maize seeds increased and seed germination indices (SGI) were reduced with increases in concentrations of the mixed rice + desmodium, rice + mucuna, and rice + maize leachates. Delayed seed germination with both type and leachate concentrations may be attributed to increased molecular interactive effects of mixed molecules of the compounds in root leachates at higher concentrations on processes that affect germination of seed such as seed respiration and apical development. Kaiira et al. (2019) profiled three terpenoids namely tert-Amylbenzene, p-ethyltoluene, 1-Sec-butyl-4methylbenzene, an alkane identified as 2,3-Dimethylundecane and one furan called 2-n-Pentylfuran as common secondary metabolites in the root exudates of upland NERICA1 and Desmodium uncinatum. The researchers also profiled 1,2-Dimethyl-4-ethyl benzene and 1,3-Ditertiarybutylbenzene terpenoids as common compounds in root exudates of upland rice NERICA 1 and Mucuna pruriens. Rice and LONGE $6 \mathrm{H}$ maize were reported to release in common 1-Methyl-2-(2-propenyl) benzene and 2-n-Pentylfuran terpenoids in their root exudates. The profiled secondary metabolites could have negatively interacted additively at higher concentrations of the mixtures on crop processes that promote seed germination, reducing the seed germination rates, and delaying the time to germination of the seedlings. Nishihara et al. (2005) and Xu et al. (2010) observed a correlation between radicle growth inhibition, seedling development, and the concentration of root diffused allelochemicals. Esfandiar et al. (2012) observed higher effects of increasing extract concentrations on germination percentage of crops and roots of crop species were more affected than the shoots. Kato-Noguchi (2011), Cai and Mu (2012) and Aliloo et al. (2015) observed that higher concentration extracts, inhibited primary root elongation and lateral root development, decreased root hair length and density, and thus inhibited cell division in root tips. Blouin et al. (2004), Li et al. (2010), and Farooq et al. (2011) have reported effects of molecular biological exchange rates to occur additively, synergistically, or antagonistically under allelopathic interactions.

Rice + mucuna mixed leachates recorded higher MGT than rice + desmodium and rice + maize mixed leachates. This may be attributed to additive and antagonistic effects by secondary metabolites in leachates of the crops. Kaiira et al. (2019), reported 1,3-ditertiarybutylbenzene and 1,2-dimethyl-4-ethyl benzene as common terpenoids in the rice and mucuna crops root exudates. The two terpenoids could have additively inhibited germination processes and by synergy with three terpenoids released in M. pruriens root exudates namely naphthalene, 1-ethyl-3-methyl-benzene and 1,3-dichloro-benzene delayed the seed germination. The two common terpenoids in rice and mucuna root exudates could have also by synergy interacted with the five terpenoids profiled exclusively in NERICA 1 root exudates as 1,2-dimethyl-3-Ethylbenzene, 1-methyl-2-(propenyl) benzene, tert-Amylbenzene, 1-sec-butyl-4 methylbenzene and pentamethylbenzine by Kaiira et al. (2019), to reduce the seed germination.

Rice and desmodium exudated 2,3-dimethylundecane, 1-sec-butyl-4-methylbenzene, tert-amylbenzene, 2-ethyl-p-xylene and 2-pentylfuran as common metabolites in the root exudates. The metabolites could have interacted additively and by synergy with 1,2-dimethyl-3-ethylbenzene, 1-methyl-2-(propenyl) benzene and pentamethylbenzine of rice reduced the germination of mucuna, desmodium, rice and maize seeds. The effects of molecular biological exchange rates were lower than under rice + mucuna mixed leachates. Rice and maize released 2-n-pentylfuran, 1-methyl-2-(2-propenyl) benzene and 2-Ethyl-p-xylene as common terpenoids that 
could have expressed lower additive biological exchange rates than exhibited by rice + desmodium mixed extracts, resulting into higher germinations expressed by lower MGT and higher SGI. The terpenoids identified as m-ethyltoluene, o-dichlorobenzene; 1,2,4-trimethylbenzene and 1,2,3-trimethyl benzene of maize could have also interacted by weak synergistic molecular biological exchange rates with 1,2-dimethyl-3-ethylbenzene and pentamethylbenzine terpenoids profiled in the root exudates of rice to reduce the seed germination of mucuna, desmodium, rice and maize. The effects of molecular biological exchange rates were lower than under rice + desmodium and rice + mucuna mixed leachates.

The reduced maize seed germination time and reduced SGI for desmodium seed under rice + maize leachates relative to other treatments, higher SGI for maize than for the control at increased rice + desmodium and rice + maize leachate concentration is attributed to antagonistic effects on the interactions of molecules in the rice + maize and rice + desmodium mixed leachates. This is a form of hormesis, a condition of stimulated growth due to low concentrations of an allelochemical similar to auxin hormones. Kaiira et al. (2019) profiled four metabolites namely 1,2,4-trimethylbenzene, 1,2,3-trimethyl benzene, o-dichlorobenzene and m-ethyltoluene in maize root exudates while rice root exudates had nine different metabolites identified as seven terpenoids namely 1-sec-butyl-4 methylbenzene, tert-amylbenzene, 1,3-di-tert-butylbenzene, pentamethylbenzine; 1,2-dimethyl-3ethylbenzene, 1-methyl-3-propylbenzene, 2-ethyl-3-propylbenzene and two alkanes called 3,5 dimethyloctane and 2,3-dimethylundecane. Six of the terpenoids namely pentamethylbenzine, 1-methyl-2-(2-propenyl)benzene, 1-methyl-3-propylbenzene, 1,3,di-tert-butylbenzene, 1,2-dimethyl-3-ethyl benzene, 2-ethyl-3-propylbenzene and an alkane called 3,5-dimethyloctane identified in rice root exudates were not profiled in desmodium which exudated three terpenoids namely 1-sec-butyl-4-methylbenzene, tert-amylbenzene, 2-ethyl-p-xylene, one alkane named 2,3-dimethylundecane and a furan called 2-pentylfuran in the root exudates. The allelopathic effects of molecular biological exchange rates under rice + maize and rice + desmodium root leachates antagonistically stimulated maize seed germination.

Mucuna seeds SGI was not influenced by mixed rice + mucuna leachate concentrations, but were reduced relative to the control. The result is attributed to antagonistic molecular exchange effects, since rice and mucuna had no common secondary metabolites to additively reduce the germination of mucuna seeds. The molecular exchange effects were however higher than under the control because of possible synergistic negative molecular effects on seed germination by the profiled terpenoid metabolites, namely1-sec-butyl-4 methylbenzene, tert-amylbenzene, pentamethylbenzine, 1,3,di-tert-butylbenzene and 1-methyl-2-(2-propenyl)benzene with rice and naphthalene, 1-ethyl-3-methyl-benzene, n-tetradecane, 1,3-ditertiarybutylbenzene, 1,3-dichloro-benzene and 1,2-dimethyl-4-ethyl benzene profiled in the root exudates of mucuna by Kaiira et al. (2019).

\subsection{Effects of Leachate Concentrations on Maize Growth and Biomass}

The increased maize seed germination indices, growth and development due to higher rice + maize and rice + desmodium leachate concentrations and potting maize with mucuna or desmodium may be attributed to hormesis common with allelochemicals. Hormesis is the stimulation of growth at suboptimal levels of allelochemical concentrations common in herbicides which mimic the growth hormone auxin but lethal at higher doses (Farooq et al., 2011). The growth condition possibly resulted from antagonistic interactions in modes of action for the metabolites of different classes namely 3-dimethyloctane alkane of rice, $p$-Ethyltoluene terpenoid of desmodium and four terpenoids of maize namely o-dichlorobenzene, 1,2,4-trimethylbenzene, m-ethyltoluene and 1,2,3-trimethyl benzene. Mucuna root exudates were reported to release five terpenoids namely naphthalene; 1,2-dimethyl-4-ethylbenzene, 1,3-ditertiarybutylbenzene, 1-ethyl-3-methyl-benzene and 1,3-dichloro-benzene, an alkane called n-Tetradecane and a phenol identified as dihydrocarveol (Kaiira et al., 2019). Abbas et al. (2017) reported that application of allelopathic water extracts for weed control boosted crop growth directly or indirectly. Glyphosate has been reported to cause 30\% increased growth in both soybean and maize by Velini et al. (2008). Cedergreen and Olesen (2010) similarly reported hormesis where glyphosate promoted crop growth. Kaya et al. (2009) attributed hormesis to enhancement of physiological processes such as photosynthesis, respiration, increased gaseous exchange and stabilization of the plants photosynthetic pigment system. Belz and Duke (2014) remarked that the studies with herbicides are not done in sufficient detail to measure hormesis. Therefore, in many experiments hormesis has not been found, reported, or has been even disregarded as outlier data.

\subsection{Effects of Potting Rice, Maize, Mucuna and Desmodium of Crop Growth}

The root, stem, and leaf growth for rice, mucuna, maize and desmodium were influenced by potted companion crops. This is attributed to influences of the different secondary metabolites in the root exudates of the crops on processes such as synthesis of lipids, proteins, amino acids, respiration, and photosynthesis needed for crop growth and development. 


\section{Conclusions}

The study demonstrated crop allelopathic properties expressed as reduced weed and crop growth using mucuna, desmodium, maize, and rice leachates in the pot screening experiment and with root exudates of mucuna, maize and rice in the equal compartment agar study. Rice, mucuna, and desmodium growth were reduced as donor-receiver crops in the same pots. The relative growth changes may lead to late crop establishment and reduced crop competitive advantage, resulting in the formation of different crop age structures within the populations under mixed cropping systems. Crops with age structures are characterised by low productivity levels. Herbicide hormesis was observed, but it lacks wide practical implementation. Therefore, more research is needed to understand how to exploit herbicide hormesis potential benefits and to minimize possible harmful effects in crop production. Hormesis is a potential area for further allelopathic investigations with rice, maize, and mucuna crop interactions. The properties identified in this study indicate the need for strategic management of sole crops, component crops, and crops under succession in different ecosystems.

\section{References}

Abbas, T., Nadeem, M. A., Tanveer, A., Ali, A. A., \& Farooq, N. (2017). Role of allelopathic crop mulches and reduced doses of tank-mixed herbicides in managing herbicide resistant Phalaris minor in wheat. Crop Protection, 110, 245-250. https://doi.org/10.1016/j.cropro.2017.06.012

Aliloo, A. A., Mustafavi, S. H., \& Ezzati, F. (2015). Allelopathic potential of Chrozophora tinctoria on early growth of barley and wheat. Azarian J. of Research, 2(1), 12-18.

AOSA (Association of Official Seed Analysis). (1983). Seed vigor hand testing book. Contribution No. 32 to the handbook on seed testing. Springfield. Springfield, IL.

Ashraf, R., Sultana, B., Yaqoob, S., \& Iqbal, M. (2017). Allelochemicals and crop management: A review. Current Science Perspectives, 3(1), 1-13.

Ayeni, M. J., \& Kayode, J. (2014). Laboratory studies on the effects of aqueous extracts from Sorghum bicolor stem and Zea mays (roots and tassel) on the germination and seedling growth of okra (Abelmoschus esculentus L.). Advances in Agriculture, 2014, Article ID 958503. https://doi.org/10.1155/2014/958503

Belz, R. G., \& Duke, S. O. (2014). Herbicides and plant hormesis. Pest Management Science, 70(5), 698-707. https://doi.org/10.1002/ps.3726

Blouin, D. C., Webster, E. P., \& Zhang, W. (2004). Analysis of synergistic and antagonistic effects of herbicides using nonlinear mixed-model methodology. Weed Technology, 18(2), 464-472. https://doi.org/ 10.1614/WT-03-047R1

Cai, S. L., \& Mu, X. Q. (2012). Allelopathic potential of aqueous leaf extracts of Datura stramonium L. on seed germination, seedling growth and root anatomy of Glycine max L. Merrill. Allelopathy J., 30(2), 235-245.

Cedergreen, N., \& Olesen, C. F. (2010). Can glyphosate stimulate photosynthesis? Pesticide Biochemistry and Physiology, 90(3), 140-148. https://doi.org/10.1016/j.pestbp.2009.11.002

Datta, S., \& Saxena, D. B. (2001). Pesticidal properties of parthenin (from Parthenium hysterophorus) and related compounds. Pest Management Science, 57(1), 95-101. https://doi.org/10.1002/1526-4998(200101) 57:1 $\leq 95:: A I D-P S 248>3.0 . C O ; 2-\mathrm{J}$

Dayan, F. E., Howell, J., \& Weidenhamer, J. D. (2009). Dynamic root exudation of sorgoleone and its in planta mechanism of action. J. of Experimental Botany, 60(7), 2107-2117. https://doi.org/10.1093/jxb/erp082

Esfandiar, F., Samaneh, S. S., \& Farzad, G. (2012). Evaluation of the allelopathic effect of bindweed (Convolvulus arvensis L.) on germination and seedling growth of millet and basil. Advances in Environmental Biology, 6(3), 940-950.

Esmaeili, M., \& Heidarzade, A. (2015). Enhance the allelopathic potential of two rice cultivar (Oryza sativa L.) by foliar application of salicylic acid under salinity stress. International J. of Biosciences, 6(4), 177-183. https://doi.org/10.12692/ijb/6.4.177-183

Farooq, M., Jabran, K., Cheema, Z. A., Wahid, A., \& Siddique, K. H. M., (2011). The role of allelopathy in agricultural pest management. Pest Management Science, 67(5), 493-506. https://doi.org/10.1002/ps.2091

Hagan, D. L., Jose, S., \& Lin, C. H. (2013). Allelopathic exudates of cogon grass (Imperata cylindrica) Implications for the performance of native pine savanna plant species in the southeastern US. $J$. of Chemical Ecology, 39(2), 312-322. https://doi.org/10.1007/s10886-013-0241-z 
Hilt, S., Beutler, E., \& Bauer, N. (2012). Comparison of methods to detect allelopathic effect of submerged macrophytes on green algae. J. of Phycology, 48(1), 40-44. https://doi.org/10.1111/j.1529-8817.2011. 01106.X

Hooper, A. M., Caulfield, J. C., Hao, B., Pickett, J. A., Midega, C. A. O., \& Khan, Z. R. (2015). Isolation and identification of Desmodium root exudates from drought tolerant species used as intercrops against Striga hermonthica. Phytochemistry, 117, 380-387. https://doi.org/10.1016/j.phytochem.2015.06.026

Kaiira, M. G., Chemining'wa, G. N., Ayuke, F., \& Baguma, Y. (2019). Profiles of compounds in root exudates of rice, cymbopogon, desmodium, mucuna and maize. J. of Agricultural Sciences, 64(4), $399-412$. https://doi.org/10.2298/JAS1904399K

Kato-Noguchi, H. (2011). Barnyard grass-induced rice allelopathy and momilactone B. J. of Plant Physiology, 168(10), 1016-1020. https://doi.org/10.1016/j.jplph.2010.12.021

Kaya, C., Tuna, A. L., \& Yokaş, I. (2009). The role of plant hormones in plants under salinity stress. In M. Ashraf, M. Ozturk, \& H. Athar (Eds.), Salinity and Water Stress (pp. 45-50). Tasks for Vegetation Sciences (Vol. 44). Springer, Dordrecht. https://doi.org/10.1007/978-1-4020-9065-3_5

Kong, C. H., Wang, P., Zhao, H., Xu, X. H., \& Zhu, Y. D. (2008). Impact of allelochemicals exuded from allelopathic rice on soil microbial community. Soil Biology and Biochemistry, 40(7), 1862-1869. https://doi.org/10.1016/j.soilbio.2008.03.009

Li, Z. H., Wang, Q., Ruan, X., Pan, C. D., \& Jiang, D. A. (2010). Phenolics and plant allelopathy. Molecules, 15(12), 8933-8952. https://doi.org/10.3390/molecules 15128933

Namkeleja, H. S., Tarimo, M. T., \& Ndakidemi, P. A. (2013). Allelopathic effect of aqueous extract of Argemone mexicana L. on germination and growth of Brachiaria dictyoneura L. and Clitoria ternatea L. American J. of Plant Sciences, 4(11), 2138-2147. https://doi.org/10.4236/ajps.2013.411266

Nishida, N., Tamotsu, S., Nagata, N., Saito, C., \& Sakai, A. (2005). Allelopathic effects of volatile monoterpenoids produced by Salvia leucophylla: Inhibition of cell proliferation and DNA synthesis in the root apical meristems of Brassica campestris seedlings. J. of Chemical Ecology, 31(5), 1187-1203. https://doi.org/10.1007/s10886-005-4256-y

Nishihara, E., Parvez, M. M., Araya, H., Kawashima, S., \& Fujii, Y. (2005). L-3-(3,4-dihydroxyphenyl) alanine (L-DOPA), an allelochemical exuded from velvet bean (Mucuna pruriens) roots. Plant Growth Regulation, 45(2), 113-120. https://doi.org/10.1007/s10725-005-0610-x

Nwaichi, E. O., \& Edward, O. A. (2010). Allelopathy as expressed by Mucuna pruriens and the possibility for weed management. International J. of Plant Physiology and Biochemistry, 2(1), 1-5.

Pickett, J. A., Hamilton, M. L.,Hooper, A. M., Khan, Z. R., \& Midega, C. O. A. (2010). Companion cropping to manage parasitic plants. Phytopathology, 48, 161-177. https://doi.org/10.1146/annurev-phyto-073009114433

Pieterse, P. J. (2010). Herbicide resistance in weeds-A threat to effective chemical weed control in South Africa. South African J. of Plant and Soil, 27(1), 68-73. https://doi.org/10.1080/02571862.2010.10639971

Rice, E. L. (1984). Allelopathy (2nd ed., p. 422). Academic Press, New York.

Rizvi, S. J. H., Haque, H., Singh, V. K., \& Rizvi, V. (1992) A discipline called allelopathy. In S. J. Rizvi (Ed.), Allelopathy: Basic and Applied Aspects (pp. 1-8). Chapman \& Hall Publishers. https://doi.org/10.1007/ 978-94-011-2376-1_1

Singh, H. P., Batish, D. R., \& Kohli, R. K. (1999). Autotoxicity: Concept, organisms, and ecological significance. Critical Reviews in Plant Sciences, 18(6), 757-772. https://doi.org/10.1080/07352689991309478

Soares, A. R., Marchiosi, R., Signeira-Soares, R., Barbosa de Lima, R., Dantas dos Santos, W., \& Farrarese-Filho, O. (2014). The role of L-DOPA in plants. Plant Signaling and Behavior, 9(4), Article e28275. https://doi.org/10.4161/psb.28275

Velini, E. D., Alves, E., Godoy, M. C., Meschede, D. K., Souza, R. T., \& Duke, S. O. (2008). Glyphosate at low doses can stimulate plant growth. Pest Management Science, 64(4), 489-496. https://doi.org/10.1002/ ps.1562

Xu, F., Tan, X., \& Wang, Z. (2010). Effects of sucrose on germination and seedling development of Brassica napus. International J. of Biology, 2(1), 150-154. https://doi.org/10.5539/ijb.v2n1p150 
Zohaib, A., Abbas, T., \& Tabassum, T. (2016). Weeds cause losses in field crops through allelopathy. Notulae Scientia Biologicae, 8(1), 47-56. https://doi.org/10.15835/nsb819752

\section{Copyrights}

Copyright for this article is retained by the author(s), with first publication rights granted to the journal.

This is an open-access article distributed under the terms and conditions of the Creative Commons Attribution license (http://creativecommons.org/licenses/by/4.0/). 